\title{
GULF CO-OPERATION COUNCIL (GCC)
}

Origin. Also referred to as the Co-operation Council for the Arab States of the Gulf (CCASG), the Council was established on 25 May 1981 on signature of the Charter by Bahrain, Kuwait, Oman, Qatar, Saudi Arabia and the United Arab Emirates.

Aims. To assure security and stability of the region through economic and political co-operation; promote, expand and enhance economic ties on solid foundations, in the best interests of the people; co-ordinate and unify economic, financial and monetary policies, as well as commercial and industrial legislation and customs regulations; achieve self-sufficiency in basic foodstuffs.

Organization. The Supreme Council is formed by the heads of member states and is the highest authority. Its presidency rotates, based on the alphabetical order of the names of the member states. It holds one regular session every year, in addition to a mid-year consultation session. The Co-operation Council has a commission, called 'Commission for the Settlement of Disputes', which is attached to the Supreme Council. The Ministerial Council is formed of the Foreign Ministers of the member states or other delegated ministers and meets quarterly. The SecretariatGeneral is composed of Secretary-General, Assistant Secretaries-General and a number of staff as required. The Secretariat consists of the following sectors: Political Affairs, Military Affairs, Economic Affairs, Human and Environment Affairs, Information Centre, Media Department, Secretary-General's Office, GCC Delegation in Brussels, Technical Telecommunications Bureau in Bahrain. In Jan. 2003 it launched a customs union, introducing a 5\% duty on foreign imports across the trade bloc.

Finance. The annual budget of the GCC Secretariat is shared equally by the six member states.

Headquarters: PO Box 7153, Riyadh-11462, Saudi Arabia.

Secretary-General: Abdulrahman bin Hamad Al-Attiyeh.

Publications. GCC News (monthly, in English); Attaawun (quarterly, in Arabic); GCC Economic Bulletin (annual).

Further Reading

Twinam, J. W., The Gulf, Co-operation and the Council: an American Perspective. Washington, 1992

\section{ORGANIZATION OF THE PETROLEUM EXPORTING COUNTRIES (OPEC)}

Origin and Aims. Founded in Baghdad in 1960 by Iran, Iraq, Kuwait, Saudi Arabia and Venezuela. The principal aims are: to unify the petroleum policies of member countries and determine the best means for safeguarding their interests, individually and collectively; to devise ways and means of ensuring the stabilization of prices in international oil markets with a view to eliminating harmful and unnecessary fluctuations; and to secure a steady income for the producing countries, an efficient, economic and regular supply of petroleum to consuming nations, and a fair return on their capital to those investing in the petroleum industry. It is estimated that OPEC members possess $75 \%$ of the world's known reserves of crude petroleum, of which about two-thirds are in the Middle East.

Members. (2003) Algeria, Indonesia, Iran, Iraq, Kuwait, Libya, Nigeria, Qatar, Saudi Arabia, United Arab Emirates and Venezuela. Membership applications may be made by any other country having substantial net exports of crude petroleum, which has fundamentally similar interests to those of member countries. Gabon became an associated member in 1973 and a full member in 1975, but in 1996 withdrew owing to difficulty in meeting its percentage contribution. Ecuador joined the Organization in 1973 but left in 1992. 